\title{
Aile Sağlığı Merkezlerinde Çalışan Hemşirelerin COVID-19 Pandemisi Sürecinde Karşılaştıkları Etik Sorunlar: Bir Nitel Çalışma
}

\section{Ethical Problems Encountered by Nurses Working in Family Health Centers during the COVID-19 Pandemic: A Qualitative Study}

\author{
Melek Nihal Esin $^{1}\left(\mathbb{D}\right.$, Ayșe Dost $^{2}\left(\mathbb{D}\right.$, Nursel Gülyenli $^{1}$
}

1 İstanbul Üniversitesi-Cerrahpaşa, Florence Nightingale Hemşirelik Fakültesi, Halk Sağlığı Hemşireliği Anabilim Dalı, İstanbul, Türkiye

2 İstanbul Medipol Üniversitesi, Sağlık Bilimleri Yüksekokulu, Hemşirelik Bölümü, İstanbul, Türkiye

ORCID: M.N.E. 0000-0002-5476-9419;

A.D. 0000-0002-4651-7254;

N.G. 0000-0003-3592-3270

Sorumlu Yazar/Corresponding Author: Ayşe Dost,

İstanbul Medipol Üniversitesi, Sağlık Bilimleri Yüksekokulu, Hemșirelik Bölümü, İstanbul, Türkiye

E-posta: adost@medipol.edu.tr

Başvuru/Submitted: 13.08.2021

Revizyon Talebi/Revision Requested: 10.09.2021 Son Revizyon/Last Revision Received: 13.09.2021 Kabul/Accepted: 23.09.2021

Online Yayın/Published Online: 04.11.2021

Atıf/Citation: Esin MN, Dost A, Gulyenli N. Ethical problems encountered by nurses working in family health centers during the Covid-19 pandemic: a qualitative study. Sağlık Bilimlerinde İleri Araştırmalar Dergisi 2021; 4(Suppl.1) S51-S62.

https://doi.org/10.26650/JARHS2021-982400
ÖZ

Amaç: Bu araştırmada aile sağlığı merkezlerinde çalışan hemşirelerin COVID-19 pandemisi sırasında karşılaştıkları etik sorunların belirlenmesi amaçlandı.

Gereç ve Yöntem: Araștırma, fenomenolojik desenli bir nitel çalıșma olarak gerçekleștirildi. Araştırmanın örneklemini İstanbul İli Avrupa Bölgesỉnde yer alan yedi farklı aile sağlığı merkezinde çalıșan ve kartopu örnekleme yöntemi ile ulașlan sekiz hemșire olușturdu. Veriler Haziran-Temmuz 2021 tarihleri arasında çevrimiçi bir platform kullanılarak derinlemesine görüșme yöntemiyle toplandı ve kaydedildi. Veriler 12 sorudan oluşan görüşme formu doğrultusunda toplandı. Verilerin deşifre edilmesinden sonra MAXQDA 2020 program kullanılarak içerik analizi yapıldı.

Bulgular: Görüşmeler sonucunda dokuz kod ve 44 alt kod elde edildi. Bu kodlar; çalışma koşulları, hizmet sunumu ve psikolojik süreçler ile ilgili etik sorunlar olmak üzere üç temel kategoride ele alındı. Çalışma koşulları ile ilgili etik sorunlar kategorisinde hemşireler; fiziksel alan, kișisel koruyucu ekipman ve artan iș yüküne ilișkin sorunlarını ifade ettiler. Hizmet sunumu ile ilgili etik sorunlar kategorisinde; rutinde uygulanan hizmetlerin sunumundaki değișimler, aksayan/ertelenen hizmetler, yapılamayan hizmetler ve yeni eklenen hizmetler/ görevler kodlarının altında yaşadıkları sorunları ve zorlukları ifade ettiler. Psikolojik süreçler ile ilgili etik sorunlar kategorisinde ise pandemiye ve sürece ilişkin algıllarından ve motivasyonlarına ilişkin yaşadıkları zorluklardan bahsettiler.

Sonuç: Çalışmanın bulguları ıșığında aile sağlığı merkezinde çalışan hemşireler tarafından kronik hasta izlemlerinin yapılmaması, rutin hizmetlerin aksaması ya da gerçekleștirilememesi ve yeni verilen görevlerle iş yükünün artması gibi olumsuzluklar sıklıkla ifade edilmiş olup, uygulamaları sırasında yașadıkları etik sorunların en fazla adalet, yararlı olma ve zarar vermeme etik ilkeleriyle ilgili olduğu saptandı.

Anahtar Kelimeler: Aile sağlığı merkezi, COVID-19, etik, hemşire, pandemi

\section{ABSTRACT}

Objective: This study aimed to determine the ethical issues experienced by nurses working in family health centers during the COVID-19 pandemic.

Materials and Methods: This research was carried out as a qualitative study following a phenomenological pattern. The sample of the study consisted of eight nurses working in seven different family health centers in the European Region of Istanbul and who were added to the study using the snowball sampling method. Data were collected and recorded using the in-depth interview method on an online platform between June and July 2021. Data were collected in line with the interview form consisting of 12 questions. After transcription of the data, content analysis was performed using the MAXQDA 2020 program.

Results: In the interview, it was found that there were nine codes and 44 subcodes. These codes were handled in three main categories: working conditions, service delivery and psychological process. Nurses in the working conditions category expressed their problems regarding physical space, personal protective equipment, and increased workload. In the service delivery category, they expressed the problems and difficulties they experienced under the codes of changes in the provision of services that are routinely applied, services that are interrupted/ postponed, services that cannot be performed and newly added services/tasks. In the category of psychological processes, they talked about the difficulties they experienced regarding their perceptions and motivations regarding the pandemic and the process.

Conclusion: It was observed that the ethical problems experienced by the nurses working in the family health center during their practice were mostly related to the ethical principles of justice, beneficence, and non-maleficence. Negative aspects such as the lack of follow-up of chronic patients by the nurses, the disruption of routine services or the inability to perform them, and the increase in the workload with newly assigned tasks were frequently expressed. Keywords: COVID-19, ethic, family health center, nurse, pandemic 


\section{GİRIŞ}

Ülkemizde ilk COVID-19 tanısı 11 Mart 2020 tarihinde konulmuş ve hastalığın yayılmasını önlemek, hastaları tedavi etmek için bazı eylemler hayata geçirilmiştir. Salgın planına uygun olarak, çok sektörlü bir yaklaşım uygulanmış ve toplumu bir bütün olarak kapsayan önleyici tedbirler alınmıştır (1). Acil olmayan hastaların öncelikle aile sağlığı merkezlerinden hizmet almasının önerilmesi bu tedbirlerden biridir. Pandemi döneminde hastanelerin büyük çoğunluğunun pandemi hastanelerine dönüşmesi birinci basamak sağlık hizmetlerine olan talebi artırmış ve aile sağlığı merkezleri (ASM) hastaların ilk temas noktası haline gelmiştir $(1,2)$.

Pandemi sürecinde aile sağllğı merkezlerinde; gebe, bebek ve yaşlı nüfusun korunması ve koruyucu hizmetlerin aksatılmadan sürdürülmesi, kronik hastalıkların takibi, pandemiden etkilenenler için tedavi ve destek hizmetleri, tüm nüfus için düzenli sağlık hizmetleri, sağlık çalışanlarının korunması, desteklenmesi ve mevcut görevlere eklenen pandemi kaynaklı görevlerin yürütülmesi önem arz etmektedir (3). Bu görevlerin yerine getirilmesinde ve toplum sağlığının en üst düzeye taşınmasında sağlığı koruyan ve geliştiren hizmetleri veren aile sağllğ 1 hemşireleri önemli rol oynamaktadır (4). Pandemi sürecinde bireylerin haklarının korunması önemli olup, pandemiye yönelik bilgilendirmelerin yapılması, korunma önlemlerinin sağlanması, ihtiyaç olan tıbbi hizmetin verilmesi, dezavantajlı gruplara öncelik sağlanması ve insan onuruna saygı gösterilmesi öncelikli etik konular arasındadır (5).

Aile sağlığı merkezlerine yönelik mevcut literatür incelendiğinde, pandemi sürecinde gebe ve lohusaların takiplerini ertelediği, sağlıklı bebek, çocuk, gençlik ve 65 yaş üstü takiplerin azaldığ 1 , aile planlaması hizmetlerinin durma noktasına geldiği ancak herhangi bir şikâyeti olup muayene olmaya gelen sayısında ise ciddi bir artış olduğu, ev ziyaretlerinin azaltıldığı, triyaj için uygun alan yetersizliğine bağlı olarak olası COVID-19 vakaları ile sağlıklı bireylerin bir arada hizmet almak durumunda olduğu belirtilmektedir $(1,3,6,7)$. Toplumdaki insanların bakıma, bilgiye ve eğitime erişimi gibi haklarının ihlali, bi- reylerin hastalıklara karşı savunma gücünü azaltmaktadir (8).

$\mathrm{Bu}$ süreçte sağlık kurumlarında hemşirelerin sayısının yetersizliği, kalitesiz kişisel koruyucu ekipmanlardan dolayı tam olarak korunamaması, sağlık çalışanlarının hastalığı kendine, yakınlarına taşıma korkusundan dolayı yaşadığı anksiyete, endişe ve tükenmişlik sorunlarının olduğu, görevlerinin kapsamının belirsizliği, çalışma saatlerinin fazlalığı, çalıșma ortamının yetersizliği, rutinlerinin değişmesi gibi durumlardan kaynaklı olarak hasta bakım kalitesinin olumsuz etkilendiği ve etik sorunların gündeme geldiği belirtilmektedir (9-14).

Hemşireliğin doğasında insan haklarına saygı vardır (15). Hemşirelik uygulamalarının temeli, acıyı hafifletmek, sağlığ 1 iyileştirmek ve her hastanın haklarına ve onuruna saygı göstermektir (16). Hemşirelerden sağlıklı/hasta bireye bakım verirken özerklik, adalet, iyilik ve zarar vermeme ana ilkelerini uygulamaları beklenmektedir (17).

Aile sağlığı merkezlerinde çalışan hemşirelerin küresel sağlık krizi olan COVID-19 pandemisi sırasında karşı karşıya kaldıkları etik sorunlar hakkında sinırlı veri mevcuttur. Bu çalışmada COVID-19 pandemisi sırasında aile sağlığı hemşirelerinin karşılaştıkları etik sorunların belirlenmesi amaçlanmaktadır.

Araştırma sorusu: Aile sağllğı merkezlerinde çalişan hemşirelerin COVID-19 pandemisi sürecinde karşılaştıkları etik sorunlar nelerdir?

\section{GEREÇ VE YÖNTEM}

Araştırma Tipi: Araştırma, fenomenolojik desenli nitel bir araştırmadır.

Araştırmanın Örneklemi: Araştırma İstanbul İli Avrupa Bölgesi’nde yer alan yedi farklı aile sağlı̆̆ı merkezinde çalışan hemşireler ile gerçekleştirilmiştir. Araştırmada kartopu örnekleme yöntemi kullanılmış olup, bu yöntemle ulaşılan hemşirelerden farklı ilçelerde çalışan, eğitim düzeyi ve deneyim süresi farklı olan hemşirelerle görüşmeler gerçekleştirildi. Görüşmeler verilerin doygunluğa erişmesi nedeniyle sekiz hemşire ile yapıldı.

\section{Verilerin Toplanması}

Veriler, Haziran-Temmuz 2021 tarihleri arasında 
çevrimiçi bir platform kullanılarak derinlemesine görüşme yöntemiyle toplanmış ve kaydedilmiştir. Görüşmeler araştırmacılar tarafından literatür doğrultusunda oluşturulmuş ve "Pandemi sürecinin rutin hemşirelik uygulamalarınız üzerine etkileri nelerdir?”, "Pandemi sürecinde hasta/sağlıklı bireylerle ilişkilerinizi nasıl görüyorsunuz?", "Hastal1ğ kendinize ya da sevdiklerinize bulaştırma korkusu verilen hizmetler üzerinde nasıl etki yarattı? Aksayan hizmetler nelerdir?" gibi 12 sorudan oluşan yapılandırılmış bir görüşme formu kullanılarak gerçekleştirilmiştir $(11,16,18)$. Görüşmeler yaklaşık 25-45 dakika içerisinde tamamlanmıştır.

\section{Araştırmanın Etik Yönü}

Çalışmaya başlamadan önce İstanbul Üniversitesi-Cerrahpaşa Sosyal Bilimler ve Beşeri Bilimler Araştırmaları Etik Kurulu’ndan 08.06.2021/107053 tarih ve sayılı etik onay alınmıştır. Aile Sağlı̆̆ 1 Merkezlerinden veri toplanmasına Sağlık Bakanlığı COVID-19 Bilimsel Araştırma Çalışmaları Komisyonu tarafindan 11.05.2021/T22_56_29 tarih ve sayılı izin verilmiștir. Tüm katılımcılar, araștırmaya dâhil olan süreçler ve verilerinin korunması hakkında bilgilendirilmiştir. Görüşmelerin başında, görüşmelerin kayıt altına alınacağ katılımcılara bildirilmiş, çalışma için bilgilendirilmiş yazılı onayları alınmıştır.

\section{Verilerin Analizi}

Nitel araştırmadan elde edilen verilerin analizi için ses kayıtları dinlenerek görüşmeler deşifre edilmiştir. Verilerin transkripsiyonundan sonra araştırmacılar tarafindan tekrarlayan dinlemelerle kontrolleri yapılmıştır. Görüşme formu doğrultusunda kategoriler ve kodlar oluşturulmuştur. Araştırmada içerik analizi için nitel araştırmaların veri analizinde kullanılan MAXQDA 2020 yazılımı kullanılmıştır. Kategori ve kodlara uyumlu görüşme ifadeleri katılımcılar anonim tutularak alıntılar şeklinde rapor edilmiştir.

\section{BULGULAR}

İstanbul İli Avrupa Bölgesi'nde yer alan yedi aile sağlığ 1 merkezinde çalışan sekiz hemşire ile gerçekleştirilen bu nitel çalışmada içerik analizi sonucunda üç kategori altında (çalışma koşulları, hizmet sunumu ve psikolojik süreçler) dokuz kod ve kırk dört alt kod belirlenmiştir (Şekil 1).

\section{1. Çalışma Koşulları ile İlgili Etik Sorunlar}

Bireysel derinlemesine görüşmeler sonucunda hemşirelerin çalışma koşullarına yönelik bazı sorunlar yaşadıkları görülmektedir. Bu sorunları içeren üç kod tanımlanmıştır. Çalışma koşullarında fiziksel ortam, mevcut kişisel koruyucu ekipmanın niteliği

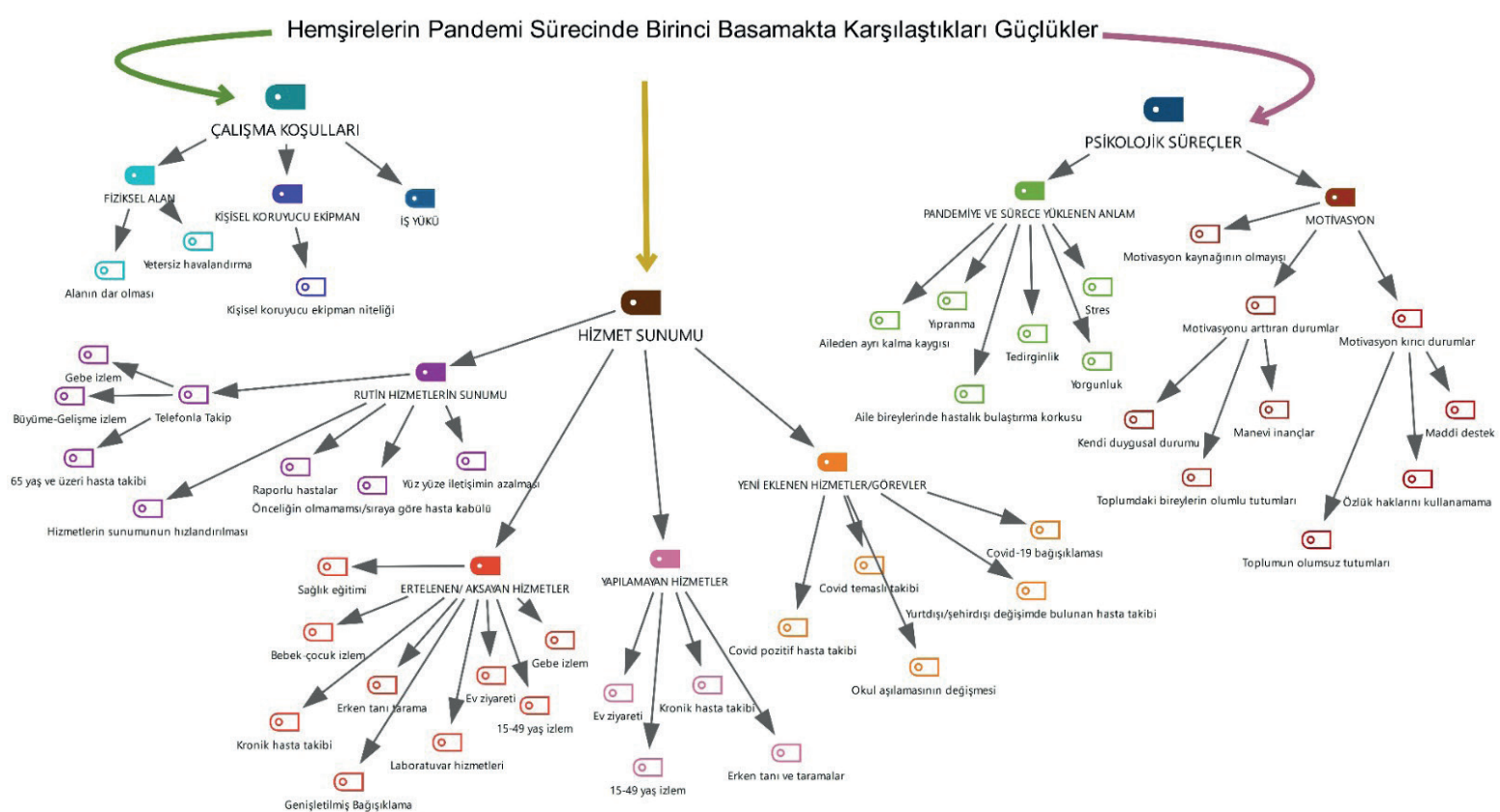

Şekil 1. Hemşirelerin pandemi sürecinde birinci basamakta karşılaştıkları etik sorunlar ile ilgili temel kod ve kavramlar 
ve artan iş yükü şeklinde sorunların olduğu görülmüştür.

Fiziksel Ortam: Hemşireler çalışma ortamında fiziksel alanın pandemi sürecindeki sosyal mesafeye uygun imkan sağlayamayacak kadar küçük olduğunu, havalandırmanın yeterli olmadığını, küçük alanlarda birden fazla kişinin bulunmak zorunda kaldığını ifade etmişlerdir. Çoğu bu sorunlara yönelik kuruma az kişi kabul edilmesi, mesafeyi belirlemek için bantların kullanılması gibi uygulamalar yaptıklarını belirtmiştir.

"Hastalar geldiğinde COVID-19 önlemlerine dikkat ediliyor. Mesafe, maske ve hijyen koşullarına dikkat ediliyor. Aşılamaya hemşire yanına geliyor. Aşı sonrası 15-20 dakika bekletebiliyoruz alanın kısitl olması nedeniyle. Dışarıda beklettiğimiz hastalarımız oluyor. ...Covid-19 şüpheli hasta varken ASM'ye gelen anneler olursa bebek aşısı için yapmayıp erteliyor, hemen evlerine gönderiyoruz." (Hemşire 8, kadın, 32 yaş)

Tüm bu önlemlere karşın düzenlemelerin çoğu zaman yetersiz olduğunu ve birden fazla hastaya aynı alan içinde girişim yapmak zorunda kaldıklarını belirtmişlerdir.

"Çalışma ortamımız güvenli değil. Bizim oda küçücük. Bir odada 5 hemşire çalışıyoruz. COVID aşısı, bebek aşısı, bebek-çocuk izlemi, gebe izlemi, yetişkin takibi hepsini ayn odada yapryoruz. Bir tek enjeksiyon odamiz ayri, laboratuvar odası ayri. Emzirme, bilgilendirme herşeyi diğer odada yapıyoruz. Cam yok, yerin altında kalıyoruz. Hava almamız için bir mazgal yaptılar bize." (Hemşire 4, kadın, 35 yaş)

Kişisel Koruyucu Ekipman: Birinci basamakta çalışan hemşirelerin çalışma ortamlarına ilişkin bir diğer yaşadıkları sorun kişisel koruyucu ekipmandır. Hemşireler pandeminin başlangıcında ekipman eksikliği yaşadıklarını ancak bunun kısa sürede giderildiğini ifade etmişlerdir. Sadece kuruma gelen N95 maskelerin sayısının yeterli olmadı̆̆ını belirtmişlerdir. Kişisel koruyucu ekipmanda niceliksel sorundan daha çok nitelikle ilgili sorunlar olduğundan bahsetmişlerdir. Gönderilen maskelerin koruyuculuğuna ilişkin endişelerini ifade etmişlerdir.

"İlk başta yeterli ekipman bulamadik. Ancak daha sonraları temin edebildik. İhtiyacımız olduğunda ara- yıp getiriyorlar. Ancak getirilen maskelerin kalitesi yetersiz... Çoğu zaman biz kendimiz satın aldik maskelerimizi. Bir tane koruyucu siperlik geldi. N95 dört doktora geldi. Bize gelmedi. Kişisel donanımın dağılımı eşit olmadı." (Hemşire 4, kadın, 35 yaş)

"Ekipman konusunda sıkıntı yoktu. Maskelerimizin malzeme kalitesi biraz düşüktü. Hemşire başına dörder N95 maske verilmişti bir kereliğine mahsus." (Hemşire 7, kadın, 43 yaş)

Artan İs Yükü: Pandemi sürecinde birinci basamaktaki hemşireler, sunulan hizmetlerin rutin devam ediyor olması, yeni görevlerin eklenmesi, bazı aile sağlığı merkezlerinde hemşireye kendi görev yetkisi dışında işlerin de verilmesi gibi süreçlere bağlı olarak iş yüklerinin arttığını ifade etmişlerdir.

"Illk günler çok kötüydü. Hepimiz günde 120 hasta falan arlyorduk. Elimizi telefondan indiremiyorduk. Kendi işlerimizi çok yapamadik. Şu anda da aşılamalardan dolayı aynı aksaklığı yaşıyoruz. Bebek, çocuk, gebe takibi gibi birinci basamak hizmetlerin hiçbirini yapamaz duruma geldik... Bir şey yapılması gerekiyorsa sürekli hemşireye verildi. Görev yetkimiz dışında işler yapmaya başladık. Yetişemiyoruz ve eksikler olmaya başladı." (Hemşire 4, kadın, 35 yaş)

"Gebe, çocuk ve bebek izlem, aşılamalar aksadr. Sıkıntılı bir süreç açıkçası... Hizmetlerimizi yetiştiremiyoruz." (Hemşire 5, kadın, 26 yaş)

"İşyükü arttı. Psikolojik olarak baskı altında olmak iş yüküyle birlikte daha kötü oldu." (Hemşire 6, kadın, 24 yaş)

\section{Hizmet Sunumu ile İlgili Etik Sorunlar}

Görüşmelerde hemşirelerin birinci basamak sağlık kurumlarında sunulan hizmetlere ilişkin ifadeleri incelendiğinde dört kod tanımlanmıştır. Hizmet sunumuna ilişkin rutinde yapılan hizmetlerin farklı şekilde sunulması, aksayan/ertelenen hizmetler, yapılamayan hizmetler ve yeni eklenen görevlere ilişkin güçlükler yaşadıkları belirlenmiştir.

Rutin Hizmetlerin Sunumu: Hemşireler birinci basamak sağlık kuruluşlarında sunulan rutin hizmetlerin farklı şekilde sunulmaya başlandığını iletmektedirler. Hemşireler hassas grupların içerisinde yer alan çocuk, gebe, 65 yaş ve üzeri bireylere telefonla hizmet sunumu yaptıklarını belirtmişlerdir. Ancak 
bu grupların hemşirelerin kendi birim nüfusları içerisinde büyük bir kısmı karşılaması nedeniyle iş yükü artmıştır ve hemşireler çoğu zaman bu hizmetlere yetişemediklerini ifade etmişlerdir.

"Gebe izlemlerini yaptık hiç birisini ötelemedik. Onlara öncelik tanıdık, odalarını ayırdık. En azından bebeklerle ayn odada beklemelerini engelledik. Kan alımlarında istemlerini yaptırıp öncelikle onlarm tahlillerini yaptırdik. İzlemlere gelmeyenleri telefonla aradik. Tedirginlikleri çok fazlaydr. Özel hastaneden takipli oldukları için telefonla izlemlerini yapıyorduk. Tetanoz aşısına geliyorlardı. Sürekli iletişim halinde oluyoruz. Telefonla bilgilerini aldığımız hastalarımızı dış izlem olarak giriyoruz." (Hemşire 6, kadın, 24 yaş)

"Anneler çocukların getirmek istemiyorlardı. Çocuk izlemlerine de gelmek istemediler, telefonla izlemlerini gerçekleştirmeye çalıştık. Aşılarında kuruma getiriyorlardı." (Hemşire 7, kadın, 43 yaş)

"Pandemi nedeniyle gelmek istemiyor bazıları. Kendileri evde yapmak istediler. Bu hastalarda telefonla izlem yapıldı." (Hemşire 8, kadın, 32 yaş)

Kronik hastalığı olan bireylerin ve yaşlı bireylerin ilaçlarının raporlu olmasından dolayı direkt eczaneden temin etmeleri, hemşirelerin bu hastalara yönelik yaptığ 1 izlemi pandemi sürecinde azaltmıştır.

"Mesela raporlu ilaçları var yaşlı hastaların. Pandemi öncesinde bunu gelip mutlaka yazdırıyorlardı hani alabilmek için bize uğruyorlardı. Şimdi raporlu olan hastalar gelmediler, direkt eczaneden alabildiler." (Hemşire 1, kadın, 34 yaş)

Bunun yanı sıra fiziki alanına göre sosyal mesafenin korunmasının güç olduğu aile sağlığı merkezlerinde hastaların genellikle randevusuz geldiğini ve öncelik sıralaması yapmak istendiğinde hastalar tarafından olumsuz tutumla karşılaştıklarını bu nedenle öncelik sıralamasının yapılamadığını ve hastaların işlemlerini kuruma geliş sırasına göre yaptıklarını belirtmişlerdir.

"Hizmetler daha hizh bir şekilde yapıldı. Telefonla görüşerek tamamlanıyordu. Bazen aciliyeti olmayan hastalar geliyordu. Erteleyebilirse ertelemesini istiyorduk ancak erteleyemiyors a hizmet veriliyordu. Direkt şikayeti olanları öncelikli olarak alamadık çünkü çok fazla öncelikli başvuru vardı. O yüzden sırayla aldık."(Hemşire 2, kadın, 42 yaş)
"Aciliyet diye bir şey yok, herkes acil olduğu için. Geliş sırasına göre hizmet sunduk." (Hemşire 5, kadın, 26 yaş)

Bu yoğun ortamda teması azaltmak için bebek ve gebeler hariç olmak üzere hastalarla yüz yüze iletişimin olabildiğince azaltıldığı, hizmet sunumunun daha hızlı ve kısa sürede yapıldığını ifade etmişlerdir.

"Daha hızl bir şekilde işi halletmeye çalışıyoruz. Hem de temas olmaması için..." (Hemşire 2, kadın, 42 yaş)

"Teması azaltmak içi hizmetler daha hızlı oldu. İletişim yüz yüze azaltıldı."(Hemşire 6, kadın, 24 yaş)

"Tüm hastalarda oluyor diyemem ama bazılarnda oluyor. Hastalıkla ilgili sorularda kısaltılmadı ama bazı ailesel sıkıntılarını anlattıkları durumlarda hızlandırdığım oldu. Enjeksiyonlarda hızh olduk. Bebeklerde böyle bir şey söz konusu değil”. (Hemşire 8, kadın, 32 yaş)

Ertelenen/Aksayan Hizmetler: Bir diğer sorun rutinde sunulan ancak pandemi sürecinde aksayan hizmetlerdir. Hemşireler pandemi sürecinin başından itibaren bebeği veya çocuğu olan hastalarının ve gebelerinin kuruma başvurmaktan çok çekindiklerini, bu sebeple izlemlerini ve aşılarını zamanında yaptırmak istemediklerini, bir süre bekleyip daha sonra yaptırmayı tercih ettiklerini ifade etmişlerdir. Diğer tarama ve izlemlerde de bireylerin pandemiye ilişkin korkularından dolayı kuruma başvurmadıklarını belirtmişlerdir. Genel olarak aksayan hizmetlere bakıldığında; bağışıklama, büyüme-gelişme taramaları, gebe izlem, erken tanı ve tarama, 15-49 yaş izlem, sağlık eğitimi, laboratuvar hizmetleri, ev ziyaretleri, kronik hasta takibi gibi hizmetlerin ertelendiğini belirtmişlerdir.

"Yani 15-49 yaş izlemleri kuruma gelen, başka bir nedenle gelmiş, işte bebeğiyle gelmiş ya da laboratuvar için gelmiş, o tarz hastalarımıza yapabildik, onun dişında kimseye yapamadık diyebilirim. Çünkü gelen olmadı. Bu tarz şeylerde kadın sağ̆lğında çok telefonla yürümüyor. İnsanlar bu tarz konularda iletişimlere girmek istemiyorlar. Gelen hastalarımıza uyguladik ama çoğunlukla eksik kaldı. Ben hemen hemen hedef nüfusumu HPV olarak 5 yılda bir yapıyorum zaten. Hepsine hemen hemen ulaşmıştım. Bu pandemi dö- 
neminde işte toplam 1.5 yılda 5-6 tane anca almışımdır." (Hemşire 1, kadın, 34 yaş)

"Aşıda pandemi döneminde ertelemeler ve retler oldu. İlk etapta çok geciktirenler oldu. 1 ay sonra ne olacak diye görmek istediler. Telefonla arayarak aşılamaları hatırlatıldı." (Hemşire 4, kadın, 35 yaş)

"Smear taramaları azaltıldı. Hastalar korktukları içi gelmiyorlardı."(Hemşire 8, kadın, 32 yaş)

Yapılamayan Hizmetler: Birinci basamak sağllk kurumlarının bazılarında pandemi süreci ve kurumdaki personellerin yoğunluğu nedeniyle erken tanı ve taramalar, 15-49 yaş izlem, kronik hasta takibi ve ev ziyaretlerinin yapılamadığı belirtilmiştir.

"15-49 yaş izlemi yoğunluktan dolayı yapamadım." (Hemşire 4, kadın, 35 yaş)

"Evde sağllk hizmetleri devam etmedi. Çünkü talepte azaldi. Çok zor durumda olana gidildi ya da evde sağlık hizmetlerine bildirildi. Şu anda yapılmıyor. Yapilmayan uygulamalardan birisi de buydu."(Hemşire 6, kadın, 24 yaş)

"Kronik hasta takibi yapılmıyordu. Yeni zorunlu yapılma durumuna geçildi. Buna yönelik eğitimler yapılmadı nasıl yapılacağına dair. Ayrıca nüfusumuzdaki kronik hasta sayısı çok fazla... Birçok izlem yapılması gerekiyor. Aynı zamanda aşılamalar, COVID'e ilişkin uygulamalar devam ediyor." (Hemşire 8, kadın, 32 yass)

Yeni Eklenen Hizmetler ve Görevler: Pandemi sürecinde birinci basamak sağllk kurumlarına yeni hizmetler eklenmiştir. Bu yeni hizmetler; COVID-19 pozitif hasta takibi, temaslı takibi, yurtdışından/il dışından gelen hasta takibi, COVID-19 bağışıklamas1, zorunlu kronik hasta takibi, okul çağı aşılamasının 4 yaş aşılaması șeklinde değișmesidir.

"Bize bir iş yoğunluğu yaratan bizim için bu telefonla takipler oldu. Özellikle dişarıdan gelenler, yurtdışından gelenler, il dışı değisşikliği yapanlar, 65 yaş üstüler, COVIDiler, temashlar bunlarla tek tek iletişim kurmaya çalıştık. O dönem böyle yoğun oldu bazen yetişemedik bile. Daha sonra aşılamaya geçince hareketlendi tabi." (Hemşire 1, kadın, 34 yaş)

"Yurtdışından gelenler COVID takip listesine ekleniyordu. Onlar takip ediyorduk. COVIDli ve temash izlemi, COVID aşılamaları eklendi." (Hemşire 6, kadın, 24 yaş)
"COVID aşılamaları, ilkokul aşılamalarının ASM'lerde yapılması iş yükünü arttırdı." (Hemşire 7, kadın, 43 yaş)

\section{Psikolojik Süreçler ile İgili Etik Sorunlar}

Bireysel derinlemesine görüşmeler sonucunda hemşirelerin psikolojik olarak sorunlar yaşadıkları görülmektedir. Bu sorunları içeren iki kod tanımlanmıştır. COVID-19'a ve pandemi sürecine ilişkin algılarının olumsuz olduğu ve motivasyona ilişkin yeterince desteklenmedikleri görülmüştür.

COVID-19 ve Pandemi Sürecine İlişkin Algıları: Pandemi sürecinde ön saflarda yer alan sağlık çalışanları özellikle pandeminin ilk zamanlarında tedirginlik ve korku yaşadıklarını belirtmişlerdir. Özellikle aile bireylerine ya da çevrelerine hastalık bulaştırma korkusu, aile bireylerinden ayrı kalma korkusu gibi duyguları yoğun olarak yaşadıklarını ifade etmişlerdir. Pandemi sürecinin ilerleyen zamanlarında ise yorgunluk, yıpranma ve stres hissettiklerini belirtmişlerdir.

"Benim de bir kızım var ve ona 'acaba bir şey taşır mıyım?' endişesi oldu. Yani çokta öyle bana bir şey olur mu duygusu yaşamadım. Kopma kaygısı yaşadım. Yani ailemden ayrı kalır mıyım? Yani aslında pozitif olmuş, iyileşmek üzere olsa birlikte kalsak bu kaygıyı o kadar yaşamazdım." (Hemşire 1, kadın, 34 yaş)

"Tedirginlik, korku da var tabi ki çevrene karşı. Sağlık çalışanı olduğumuz için tabi daha fazla. Çevreye zarar verme tedirginliği var. Kızım alerjik astım hastası. Eve getirirsem ona bulaştırırsam korkum vardr." (Hemşire 6, kadın, 24 yaş)

"Stresliydi. Tedirgin oluyorsun. Tüm ailem geçirdi. Çok ağır bir şekilde atlattık. Hastanede ve yoğun bakımda yattılar. Annemde hala sekelleri var. Travmaydı benim için." (Hemşire 8, kadın, 32 yaş)

Motivasyon Kaynakları: Birinci basamakta çalışan hemşireler görüşme sırasında çok fazla motivasyon kaynaklarının olmadığını, kendi kendilerini motive etmeye çalıştıklarını belirtmişlerdir. Özellikle yıllık izinlerini, istifa haklarını kullanamadıklarını, maddi olarak destekleneceklerinin söylenmesi ama ardından destek görememeleri, toplum tarafından sağlık çalışanı oldukları için hastalık bulaştıracakmış gibi düşünülüp, damgalandıklarından motivasyonla- 
rının düştüğünü belirtmişlerdir. Ancak kendi kendilerini motive etmeye çalıştıkları, manevi olarak desteklemeye çalıştıklarını ve toplumun bazı kesimlerinden güzel sözler duymanın kendilerini motive ettiğini söylemişlerdir.

"Bir kesim tarafindan daha farklı yaklaşıldı. Hani çok fazla hasta görüyor olmamız, insanlar birbirlerine yaklaşmaya dokunmaya korkarken biz sürekli işlem halindeyiz. Her şekilde temas halindeyiz. Sanki bu sirkülasyondan dolayı biz bulaştıracağız şeklinde farklo yaklaşanlar da vardı. Yani evet iyi ki varsını diyen bir kesimimiz olduğu gibi bir kesimde böyle yaklaştı." (Hemşire 1, kadın, 34 yaş)

"Motivasyon kaynağım yok. Ek ücretlendirme yapılmadı. Geçen ay bir arkadaşıma ek ücret verildi 6 lira. O da herkese değil bazılarımıza. Sürekli ek görevler verildi ama motive edilmedik. Pozitif çıkmadığımız sürece temaslı olarak görülmedik ve çalıştık. İstifayı kapattılar, izinleri kapattılar. Herkes özveriyle çalıştı ama birde bunlar yapılınca çalışmak istemeyenlerle inatlaşıldı. Daha çok negatif bir durum oldu." (Hemşire 4, kadın, 35 yaş)

"Biz yapmazsak kim yapacak? Mecbur yapılacak bu iş. İnsanlara iyi gelmek, iyileştirmek mesleğimizin gereği... Pandemiye özgü motive eden bir şey olmad. Daha önceden var olan ayn motivasyonumla devam ettim. Savaşalım bu pandemi bitsin dedim kendime." (Hemşire 6, kadın, 24 yaş)

"Hastalarm sözlü telkinleri bizi motive etti." (Hemşire 7, kadın, 43 yaş)

\section{TARTIŞMA}

Pandemi sürecinde toplumdaki çoğu sağlık ihtiyacı ile aile sağlığı merkezlerinde çalışan sağlık personelleri ilgilenmek durumunda kaldıklarından süreci yönetebilmek için zorunlu olmayan hizmetlerin azaltılması veya ertelenmesi, ev ziyaretlerinin azaltılması veya iptali, telefon triyajının yaygın kullanımı söz konusu olmuştur $(5,19,20)$. Birçok ülkede hemşireler, yeterli kaynak ve kişisel koruyucu ekipman olmadan, çok sayıda hasta ile, personel sıkıntısı çekerek, hazırlıksız sağlık sistemleri ve tedarik zinciri başarısızlıkları ile bu pandeminin sanal kuşatması altında çalışmaktadır. Hemşireler çalışma koşulları ve hizmet sunumundaki aksaklıklardan kaynaklı olarak hasta bakımı sürecinde tatsız ve karmaşık etik zorluklarla karşı karşıyadır $(13,21)$. Hemşirelerden sağlıklı/hasta bireye bakım verirken özerklik, adalet, yararlı olma ve zarar vermeme ana ilkelerini uygulamaları beklenmektedir $(17,22)$.

Bu bölüm, aile sağllğı merkezinde çalışan hemşirelerin karşılaştıkları etik sorunları tartışmak için etik ilkeler doğrultusunda yapılandırılmıştır.

\section{Özerklik}

Bu çalışmada aile sağllğ bahsedilen düzenlemelerin kendi kurumlarında da uygulandığını, Covid-19 bulaş korkusu ile kuruma gelmek istemeyen kişilere saygı duyulduğunu ve telefonla sağlık hizmeti/danışmanlık planlandığını belirttiler. Özerklik kişinin karar verme sürecinde dışarından gelen her türlü baskı ve sınırlamalara karşı onun bireysel tercih, hak ve özgürlükleri doğrultusunda karar verebilmesini içerir (22). Bu durum hemşirelerin hastaların kararlarına saygı göstermekte olduğunu ve özerklik ilkesine yönelik sorun yaşamadıklarını göstermektedir. Ancak özerklik ilkesine uygun olan bu uygulamaların çoğu zaman iş yükünün artması nedeniyle tüm bireylere ulaşılamadığı ya da bireylerin tam anlamıyla yararlanamadığı hemşireler tarafından dile getirilmiştir. Bu durum adalet ilkesi göz önüne alındığında etik sorun olarak karşımıza çıkmaktadır.

\section{Adalet}

Pandemi sürecinde hayati olmayan bakım ve tedaviler kısıtlanmış ya da durdurulmuştur (17). Bu süreçten birinci basamak sağlık hizmetleri kapsamında yer alan takipler ve ev ziyaretleri gibi uygulamalarda etkilenmiş ve hizmet sunum şekli değişmiştir (19). İzlemler telefonla yapılmış, ev ziyaretleri kısıtlanmıştır. Bebek-çocuk, gebe, lohusa, 65 yaş ve üstü bireylerin takiplerinin azaldığı, aile planlaması hizmetlerinin durma noktasına geldiği görülmektedir $(1,20)$. Bu araştırmada katılımcı olarak yer alan hemşireler, benzer şekilde birinci basamakta yer alan büyüme-gelişme, gebe, 65 yaş ve üzeri bireylerin takiplerini telefonla gerçekleştirmiştir. Hizmet verdikleri 65 yaş üstü bireylerin çoğuna iş yoğunluğun- 
dan dolayı telefonla ulaşamadıklarını ifade etmişlerdir. Toplumdaki bireylerin sosyodemografik farklılıklarına bağlı olarak bireylerin telefona erişim ya da kullanım güçlüklerinin olması, telefonla sunulan hizmetlerden eşit bir şekilde yararlanılmamasına neden olmaktadır. Kararların alınmasında adaletli olunması ve kıt kaynakların adil dağılımı gereklidir (22). Bu doğrultuda bireylere telefonla sunulan hizmetlere herkesin ulaşamaması adalet ilkesine ilişkin sorunlar oluşmasına neden olacaktır.

Pandemi kaynaklı farklı işlerin artması nedeniyle ev ziyaretlerinin büyük oranda yapılmadığ ve kanser taramalarının azaldığı katılımcı hemşireler tarafından belirtilmiştir. İngiltere'de yapılan bir çalışmada da, pandemi sürecinde birinci basamakta yapılan kronik hastalıklı bireylerin izlemlerinde büyük oranda düşüş yaşanmıştır (19). Ülkemizde de başvuruların azalmasının yanı sıra, pandemi ile ilgili hizmetlerin öncelenmesi, COVID dışı başvuru nedenlerinin ikinci plana atılmasına neden olmuştur (20). Kronik hastalığı olan bireylerin koruyucu sağlık uygulamaları ve eksik kalan izlemleri, tanı ve tedavi almada gecikme gibi nedenlerden dolayı mortalite oranlarının artabileceği öne sürülmektedir (19). $\mathrm{Bu}$ çalışmada hemşireler, sadece kuruma başvuran kişilere erken tanı ve taramaya ilişkin hizmet sunduklarını belirtmişlerdir. Risk grubundaki bireyler ile özellikle iletişime geçerek kuruma çağırmadıklarını ifade etmişlerdir. Bu durum, toplumda görülme sıklığı yüksek olan kanserlere karşı önemli bir adım olan erken tanı ve tarama hizmetlerinden tüm bireylerin eşit bir şekilde yararlanamadığını ve adalet ilkesine yönelik sorunların yaşandığını göstermektedir. Hakkaniyetli bir sağlık hizmeti için birinci basamağın desteklenerek güçlendirilmesi, yetkilendirilmesi ve en etkin ve akılcı şekilde sağlık hizmetlerini yürütmekte rol alması için gerekenlerin yapılması önerilmektedir (20).

Aile sağlığı hemşireleri çalışma ortamının fiziksel alanının yetersizliğinden kaynaklı olarak sosyal mesafenin korunmasının güç olduğu, hastaların genellikle randevusuz geldiğini, öncelik sıralamasının yapılamadığını ve hastaların işlemlerini kuruma geliş sırasına göre yaptıklarını belirtmişlerdir. Öncelik sıralamasının yapılmaması dezavantajlı bireyler açısından olumsuz bir durumdur. Adalet, herkese eşit davranılması, herkese ihtiyaçları bağlamında aynı şekilde muamele edilmesi anlamına gelmektedir. Gereksinimlerine göre gerektiğinde farklı kişi ve gruplara, farklı müdahalelerin yapılması gerektiği anlamina da gelir (5). Pandemi sürecinde hassas grupların hizmetlerden yararlanmasında yaşanan aksaklıklar adalet ilkesine ters düşmektedir. Kişilerin bir sağlık kaynağından yararlanma şansı eşit olmalı ve bu konuda adalet ilkesinin gerekleri hakkaniyetle yerine getirilmelidir (5).

\section{Yararlı Olma}

Çalışmada aile sağlığı hemşireleri bağışıklama, büyüme-gelişme taramaları, gebe izlem, erken tanı ve tarama, 15-49 yaş izlem, sağlık eğitimi, laboratuvar hizmetleri, ev ziyaretleri, kronik hasta takibi gibi hizmetlerin ertelendiğini belirtmişlerdir. Bazı aile sağlığı merkezlerinde de pandemi kaynaklı yeni görevler ve kurumdaki personellerin yoğunluğu nedeniyle erken tanı ve taramalar, 15-49 yaş izlem, kronik hasta takibi ve ev ziyaretlerinin yapilamad1ğını ifade etmişlerdir. Özceylan ve Kolcu'nun (2020) çalışmasında da sokağa çıkma kısıtlamaları, ailelerin bebek ve çocuklarına virüs bulaşır korkusu ile sağlık kuruluşlarına başvurma çekincesi gibi nedenlerden dolayı bebek ve çocuk izlemlerinde azalma olduğu, gebelerin ve lohusaların takip amaçlı sağlık kuruluşuna başvurmayı ertelediği belirlenmiştir. Ayrıca aile planlaması hizmetlerinde de ciddi düzeyde azalma olduğu tespit edilmiş olup, bu hizmetin aksamasının sağlıklı nesiller yetiştirmek, sağlıklı aile içi nüfus planlaması ve sağlıklı gebelik ve çocuk bakımı için ciddi riskler oluşturabileceği belirtilmektedir. Koruyucu önlemlerin acil uygulamalar olarak ele alınmas1 gerektiği düşünülmektedir $(1,20)$.

Pandemi döneminde takibi en çok aksayan grup okul çağı/adelosan çocuklar olmuştur. Pandeminin ülkemizde etkilerini göstermeye başladığı Mart ayından itibaren bu takip oranlarında düşme başlamış ve okulların da tatil edilmesiyle ASM verilerinde takipler sıfıra kadar düşmüştür. Uzun bir süre okulları kapanan, belirli bir süre sokağa çıkmaları kısıtlanan bu yaş grubunun yaşlarına özgü sağlık sorunları 
önemli sonuçlar doğurabilmektedir (1). Bu araştırmada yer alan hemşireler de benzer şekilde okul çağ izlemlerinin yapılmadığını, bu gruba yönelik sadece okul çağı aşılarının yapıldığını belirtmişlerdir. Büyüme ve gelişme dönemindeki takiplerin ve sağlik eğitimlerinin yapılmaması, ilerleyen süreçlerde karşılaşılabilecek olası hastalıklara karşı bireyleri savunmasız birakacaktır. Bu durum yararlı olma ilkesi ile ilgili sorunların oluşmasına neden olacaktır.

Aile sağlığı hemşireleri kronik hastalık izlemleri, laboratuvar hizmetleri ve kanser taramalarının ertelendiğini, çoğunlukla yapılamadığını, bu hizmetlerin yalnızca başvuran kişilere verildiğini ifade etmişlerdir. Samancı (2020) da aile sağlığı merkezlerinde rutin laboratuvar tetkikleri ve kanser taramalarının ertelendiğini belirtmiştir. Rahim ağzı, meme ve kolon kanseri taramaları, hem hasta başvurularının azalması hem de personelin (hastalanması ya da pandemi birimlerine kaydırılmasına bağlı olarak) eksikliği nedeniyle azalmış ya da durmuştur (20). Tüm dikkatlerin pandemik hastalığa yöneldiği ve kaynakların neredeyse tamamının pandemiyle savaşa ayrıldığı bu sağlik ortamında, kanser ve kardiyovasküler hastalıklar gibi mortalitesi yüksek hastalıklara sahip olan bireylerin hak ettikleri bakım ve tedaviyi almaları güçleşmektedir $(3,5,19,20)$.

Pandemi sürecinde hemşireler iş yüklerinin baskısı altında oldukları için koruyucu ve sağlığı geliştiren, topluma yarar sağlayan birçok uygulamanın yetersiz yerine getirilmesi nedeniyle etik zorlukla karşı karşıya oldukları açıktır (11). Tüm bu veriler doğru olanı uygulama ahlaki zorunluluğuna sahip olan profesyonellerin, bireylere yardım etme gibi yararlı olma ilkesinde zaman zaman sorunlar yaşadıklarını göstermektedir $(23,24)$.

\section{Zarar Vermeme}

Zarar vermeme, bakımın ne hastaya ne de toplumdaki diğer kişilere zarar vermemesi ilkesini ifade eder (22). Zarar kavramı özneldir, yalnızca bireylerin bakım ve tedavi süreci ile ilgili değil, aynı zamanda etkili denetim, stratejik karar verme ve sağlık politikasıyla da ilgili olabilir. Zarar, ihmalin etik kavramıyla yakından ilişkilidir (24).

Hemşireler çalışma alanlarının uygun büyüklükte olmadığını, havalandırmanın yetersiz olduğunu ve dar alanlarda birden fazla kişinin bulunmak zorunda kaldığını ifade etmişlerdir. Hemşirelerin çoğu bu sorunlara yönelik olarak, kuruma az kişiyi alma, diğer kişileri dışarıda bekletme, mesafeyi belirlemek için bantların kullanılması gibi uygulamalar yaptıklarını belirtmiştir. Ancak COVID aşılamalarıyla birlikte yoğunluk olduğunu, bu düzenlemelerin bazen kontrol edilemediğini ve birden fazla kişiye küçük alanlarda müdahale etmek zorunda kaldıklarını iletmişlerdir. ASM'ler küçük ve sıkışık ortak alanlara sahip olduğu için asemptomatik evrede virüs dolaş1mı ve bulaş açısından yüksek riskli ortamlar olarak bilinmektedir (20). Özceylan ve Kolcu (2020) pandemi süresince ASM'lerin fiziksel koşul ve personel sayılarına göre kimilerinde girişte etkin bir triaj uygulaması yaptığı gözlenirken bazılarında bu fiziksel eksiklikler nedeniyle triaj uygulaması yapılamadığını belirtmektedir (1). Sağlam kişiler ile olası COVID-19 vakalarının bir arada bulunması durumunun zarar vermeme etik ilkesine ters düşmekte olup, bulaşı engellemek için Dünya Sağlık Örgütü (DSÖ)'nün sağlık sistemi ile tüm ilk temas noktalarında COVID-19 için tarama ve triaj önerisine uyulmalıdır $(6,25)$.

Çalışmada hemşireler pandeminin başlangıcında ekipman eksikliği yaşadıklarını, bunun kısa sürede giderildiğini ancak kuruma gelen N95 maskelerin sayısının yeterli olmadığını ve kişisel koruyucu donanımların sağlık personeli arasında eşit dağılımının olmadığını, hekimlere fazla sayıda gönderildiğini dile getirmişlerdir. Gönderilen maskelerin kalitesi ve koruyuculuğuna ilişkin endişelerini ve bazen kendilerinin dışarıdan satın aldıklarını ifade etmişlerdir. Yetersiz ya da kalitesiz kişisel koruyucu donanım olmadan göreve başlayan sağlık çalışanlarının, sadece kendilerine değil, ailelerine ve diğer hastalara da enfeksiyonu bulaştırma riski yüksektir. Bu durum zarar vermeme etik ilkesini ihlal etmektedir (17).

Zarar vermeme etik ilkesine ters düşeceği düşünülen bir başka durum ise bebek/çocuk izlemlerine gelmek istemeyen ailelerin izlemlerinin telefonla gerçekleștirilmesi sürecinde, anne/babanın bebeğin kilo, boy, baş çevresini ölçülerini evde ölçerek hemşireye iletmesidir. Bu süreçte ailenin ölçümü doğru yapabilme durumu önem arz etmektedir. Boy ve kilo ölçümü büyüme ve gelişmenin, baş çevresi ölçümü 
de beyin gelişiminin değerlendirilmesinde önemli bir göstergedir. Baş çevresinde normalin dışındaki değerler (mikrosefali, makrosefali) gelişimsel gerilikler dâhil birçok hastalığın erken habercisi olabilir (26). $\mathrm{Bu}$ izlemlerin bu konuda eğitimli ve deneyimli uzman sağlık personeli tarafından yapılması gereklidir.

\section{Ahlaki Zorluklar}

Çalışmada hemşireler hastalığı aile bireylerine ya da çevrelerine bulaştırma korkusu, aile bireylerinden ayrı kalma korkusu gibi duyguları yoğun olarak yaşadıkları ve buna bağlı olarak yorgunluk, stres ve endişe duyduklarını dile getirmişlerdir. Çalışmalar hemşirelerin, COVID-19 hastalarına bakarken hastalığa maruz kalma, yakınlarına bulaştırma ve yeni durumlarda deneyim eksikliği nedeniyle etik zorluklarla karşılaştıklarını ve bu zorlukların kaygı, korku, stres, uykusuzluk veya sinirlilik gibi zihinsel sağlık sorunlarına yol açtığını belirtmişlerdir $(9,10,27)$. Özceylan ve Kolcu (2020)'nun çalışmasında da ASM çalışanlarının anksiyetesini arttıran en önemli sebebin hastalığı kendileriyle aynı evde yaşayan birinci derecede yakınlarına bulaştırma korkusu olduğu saptanmıştır (1). Hemşireler, genellikle sevdiklerinden ayrıyken pandeminin ön saflarında çalışmak için güçlü bir ahlaki cesaret, dayanıklılık ve esnekliğe ihtiyaç duyarlar (13). Hemşirelerin güvenliği, sağlık sistemlerinin en kritik yönlerinden biridir ancak COVID-19 pandemisi hemşirelerin sağlıklarını tehdit etmektedir. Hemşireler pandemi sırasında hastalarla ilgilenirken, hastalanma olasılıklarının farkında olmalarına rağmen meslek ahlaklarının gereği olarak görevlerini yerine getirmeye devam ederler (28). Ancak hemşirelerin, hastalara yönelik bakım görevleri ile kendilerine ve aile üyelerine olan görevleri arasında denge kurmaları gerekmektedir. Pandemi nedeniyle bu görevlerin çatışması ciddi ahlaki ve duygusal sıkıntılara neden olabilmektedir (16).

\section{SONUÇ}

Sonuç olarak bu araştırmada aile sağlığı merkezinde çalışan hemşirelerin sağllğ 1 koruma, sürdürme ve geliştirmeye yönelik rollerini gerçekleştirirken adalet, zarar vermeme ve yararlı olma etik ilkelerinde sorunlar yaşadıkları görülmektedir. Yaşanan bu etik sorunlar toplumun sağlık düzeyi üzerinde olumsuz sonuçlara neden olabilmektedir. Hizmet sunumunda etik kılavuzların uygulanması daha az zorluk, daha fazla hasta memnuniyeti ve bakım kalitesine yol açacaktır. Aile sağlığı hemşirelerinin COVID-19 pandemisi sürecinde çalışma koşulları, yaşadıkları deneyimler ve karşı karşıya kaldıkları etik sorunlar ile ilişkili faktörlerin belirlenmesi üzerine odaklanan çalışmalar yok denecek kadar az olup bu konularda çalışmalara ihtiyaç olduğu düşünülmektedir.

Etik Komite Onayı: Bu çalışma için etik komite onayı İstanbul Üniversitesi-Cerrahpaşa Sosyal Bilimler ve Beşeri Bilimler Araştırmaları Etik Kurulu’ndan alınmıştır (No: 08.06.2021/107053).

Ethics Committee Approval: This study was approved by the Istanbul University-Cerrahpaşa Social Sciences and Humanities Research Ethics Committee (No: 08.06.2021/107053).

Bilgilendirilmiş Onam: Katılımcılardan bilgilendirilmiş onam alınmıştır.

Informed Consent: Written consent was obtained from the participants.

Hakem Değerlendirmesi: Dış bağımsız.

Peer Review: Externally peer-reviewed.

Çalışma Konsepti/Tasarım-M.N.E., A.D.; Veri Toplama- A.D., N.G.; Veri Analizi/YorumlamaM.N.E., A.D, N.G.; Yazı Taslağı- A.D., N.G.; İçeriğin Eleştirel İncelemesi-M.N.E.; Son Onay ve Sorumluluk- M.N.E., A.D, N.G.

Author Contributions: Conception/Design of Study- M.N.E., A.D.; Data Acquisition- A.D., N.G.; Data Analysis/Interpretation- M.N.E., A.D, N.G.; Drafting Manuscript- A.D., N.G.; Critical Revision of Manuscript-M.N.E.; Final Approval and Accountability- M.N.E., A.D, N.G.

Çıkar Çatışması: Yazarlar çıkar çatışması beyan etmemişlerdir

Conflict of Interest: Authors declared no conflict of interest.

Finansal Destek: Yazarlar finansal destek beyan etmemişlerdir.

Financial Disclosure: Authors declared no financial support. 


\section{KAYNAKLAR}

1. Özceylan G, Kolcu G, editörler. COVID-19'un birinci basamak sağlık hizmetlerine etkileri. İzmir: Meta Basım Matbaacılık Hizmetleri; 2020 .

2. Taş BG, Özceylan G, Öztürk GZ, Toprak D. Evaluation of job strain of family physicians in COVID-19 pandemic period- an example from Turkey. J Community Health 2021; 46(4): 77785.

3. Gürçiner İM. Pandemi döneminde ailehekimlerinin rolü. (Alıntılanma tarihi: 29.07. 2021): Available from: https://www.tuseb.gov.tr/ tuspe/uploads/genel/files/haberler/zirve2021_ sunumlar/MineGurciner-TUSPEZirveSunumu.pdf.

4. Sezer BA, Erol S. Aile sağ 1 ğ 1 merkezinde eleman değil hemşire olmak. Hemşirelikte Eğitim ve Araştırma Dergisi 2016; 13(3): 244-9.

5. Örnek BN. COVID 19 pandemisi ve etik konular. Sağlık ve Toplum 2020; Özel sayı: 16-26.

6. Aktura B. Aile hekimliği merkezlerinde pandemi yönetimi. The Journal of Turkish Family Physician 2020;11(1):45-7.

7. Samancı VM. Birinci basamak sağlık hizmetleri ve pandemi süreci. Konuralp Medical Journal 2020;12(S1):391-3.

8. Bagnasco A, Zanini M, Dasso N, Rossi S, Timmins F, Galanti MC et al. Dignity, privacy, respect and choice-A scoping review of measurement of these concepts within acute healthcare practice. J Clin Nurs 2020;29(1112):1832-57.

9. Chang D, Xu H, Rebaza A, Sharma L, Dela Cruz CS. Protecting health-care workers from subclinical coronavirus infection. Lancet Respir Med 2020; 8(3): e13.

10. Liu Q, Luo D, Haase JE, Guo Q, Wang XQ, Liu S, et al. The experiences of health-care providers during the COVID-19 crisis in China: A qualitative study. Lancet Glob Health 2020;8(6):e790-e798.

11. Gebreheat G, Teame H. Ethical challenges of nurses in COVID-19 pandemic: Integrative review. J Multidiscip Healthc 2021;14:1029-35.
12. Kackin O, Ciydem E, Aci OS, Kutlu FY. Experiences and psychosocial problems of nurses caring for patients diagnosed with COVID-19 in Turkey: A qualitative study. Int J Soc Psychiatry 2021;67(2):158-67.

13. Turale S, Meechamnan C, Kunaviktikul W. Challenging times: Ethics, nursing and the COVID-19 pandemic. Int Nurs Rev 2020;67(2):164-7.

14. McKenna H. Covid-19: Ethical issues for nurses. Int J Nurs Stud 2020;110:103673.

15. Sabatello M, Burke TB, McDonald KE, Appelbaum PS. Disability, ethics, and health care in the COVID-19 pandemic. Am J Public Health 2020;110(10):1523-7.

16. Morley G, Grady C, McCarthy J, Ulrich CM. Covid-19: Ethical challenges for nurses. Hastings Cent Rep 2020;50(3):35-9.

17. Shah A, Aacharya RP. Combating COVID-19 pandemic in Nepal: Ethical challenges in an outbreak. JNMA J Nepal Med Assoc 2020;58(224):276-9.

18. Isfeedvajani MS, Fares F, Moqaddam ZIS. Ethical Issues in COVID-19 Pandemic. Hosp Pract Res 2020;5(4):126-33.

19. Levene LS, Seidu S, Greenhalgh T, Khunti K. Pandemic threatens primary care for long term conditions. BMJ 2020;371:m3793.

20. Halk Sağlığı Uzmanları Derneği. Bulaşıcı Olmayan Hastalıklar Çalışma Grubu. (Alıntılama tarihi: 03.07.2021): Availablefrom: https://hasuder.org.tr/wp-content/uploads/ Bulasici-Olmayan-Hastaliklar-Calisma-Grubu. pdf.

21. American Nurses Association. Nurses, Ethics and the response to the COVID-19 pandemic. (Alıntılama tarihi: 12.07.2021): Available from: https://www.nursingworld. org/ 495c6c/globalassets/practiceandpolicy/ work-environment/health--safety/coronavirus/ nurses-ethics-and-the-response-to-the-covid19-pandemic.pdf.

22. Zhu J, Stone T, Petrini M. The ethics of refusing to care for patients during the coronavirus pandemic: A Chinese perspective. Nurs Inq 2021;28(1):e12380. 
23. Kinsinger FS. Beneficence and the professional's moral imperative. J Chiropr Humanit 2009;16(1):44-6.

24. Cousins E, Vries K, Dening KH. Ethical care during COVID-19 for care home residents with dementia. Nurs Ethics 2021;28(1):46-57.

25. World Health Organization.Clinical management of severe acute respiratory infection (SARI) when COVID-19 disease is suspected: interim guidance. (Alintılama tarihi: 13.04.2020): Available from: https://apps.who. int/iris/handle/10665/331446.
26. Daştan GS, Boran P. Ebeveyn antropometrik ölçümlerinin çocuk baş çevresi üzerine etkisi. Çocuk Dergisi 2018;18(3):113-20.

27. Iserson $\mathrm{KV}$. Healthcare ethics during a pandemic. West J Emerg Med 2020;21(3):477-83.

28. Firouzkouhi M, Alimohammadi N, Kako M, Abdollahimohammad A, Bagheri G, Nouraie M. Ethical challenges of nurses related COVID-19 pandemic in inpatient wards: An integrative review. Ethics Med Public Health 2021;18:100669. 